\title{
Perspectives: the alleged herdsmen carnage in Nigeria; changing the narrative from rhetoric's to action
}

\begin{abstract}
Looking at the past decades, conflict has become unabated in most African regions including Nigeria. This conflict has affected the lives of many men and women rendering countless people homeless and some vulnerable. This conflict has produced different kinds of atmosphere, destroying the social fabrics of most of these previously functional societies. This paper has centered on making opinions from various opinion holders' count as part of problem identification and problem solving; especially with the recurrent alleged Herdsmen carnage in North Central Nigeria. To mitigate this social ill, government, the people, and the perpetrators will have to come to the mediation table and seek for inherent solutions.
\end{abstract}

Volume 9 Issue 2 - 2018

\author{
Binan Evans Dami \\ Clinical Psychologist/Writer/Researcher/Mental Health \\ Practitioner, Nigeria
}

Correspondence: Binan Evans Dami, Clinical Psychologist/ Writer/Researcher/Mental Health Practitioner, Nigeria, Email evansbinan@gmail.com

Received: January 16, 2018 | Published: April 06, 2018

\section{Introduction}

Over the past years, conflicts of various kinds have taken charge of various regions in Nigeria, leaving a lot of societies, and human groups homeless, and some in a state of awe. What this qualifies is a state of uncertainty about people's movement from one point to another, as enshrined in the constitution. The security of a people in a country is the most paramount issue faced by countries and countries have brought out templates on how to improve their security fabrics; this reflects itself in budgetary preparations in countries such as America, UK, France, etc whereas the developing nations are still battling with rebuilding their security fabrics. The recurrent and incessant attacks on human groups have produced undesirable feelings, new opinions, new perspectives, and have rewarded a couple of happenings, especially where the seeming perpetrators are yet to be brought to book. This paper presents perspectives from different line of thoughts in respect to the persistent alleged Herdsmen attack in the North central region of Nigeria; and thus providing recommendations where need be. Let us take a walk through the current happenings around Nigeria as this will shape the nature of thoughts in our minds.

\section{A walk through the theatre of blood bath}

To be candid enough about a couple of things, I would like to think that a couple of things have gone sour and Nigerians have not been at their best to ensure that security becomes our collective responsibility. Our mission has not produced valuable imprints and we have left the farmers, the vulnerable communities, the villages, and other persons at the hands of Armed Operating Groups, and this has led to sporadic deaths mostly across the North Central States of Plateau, Benue, Nassarawa, and down to other states such as Kaduna, Enugu, Ekiti, Delta, Taraba, Adamawa, etc. To explain my point better, let me give these accounts in Plateau, Benue, Nassarawa, Kaduna, etc. About 29 persons mainly women and children killed in an attack by suspected herdsmen in Nkeidonwhro village in Bassa LGA, Plateau State (Vanguard News, October, 17, 2017). Government and community action not enough. "The Irigwe people reported that between September 8, 2017 and October 17 2017, in just five weeks, two major communities of Irigwe land were attacked and sacked. Seventy (70) people were killed, 23 injured, 489 houses burnt down, and 13,726 people out of the total population of 80,000 displaced" (Mark Lipdo, Executive Director Stephanos Foundation, October, 2017). He added that the organization has obtained reports of attacks in Benue, Plateau, Southern Kaduna, Edo, Ondo, Ekiti, and Delta states respectively. Government and community action not in place. Over 200 people killed in Dogo Na Hawa, Jos, close to Shen in Du District; at least 45 children including toddlers gunned down, others roasted, more than 75 houses razed down - Plateau State Commissioner for Information Mr. Gregory Yenlong described the attack on the villages as "ethnic cleansing" (Vanguard News, March $\left.7^{\text {th }}, 2010\right)$. Government and community action not in place Attack on Sen. Gyang Dantong, Hon. Gyang Fulani, and Hon. Simon Mwadkon, leading to the death of Dantong and Gyang Fulani while Mwadkon was taken to the hospital in an unconscious state. This happened while they were attending a burial ceremony of 50 persons killed in Barkin Ladi and Riyom a week earlier by suspected herdsmen. (Vanguard News, $9^{\text {th }}$ July, 2012). A civil right activist Mr. Gad Peter called for the sacking of all security chiefs in the country (Vanguard News, $9^{\text {th }}$ July, 2012) 9 persons killed including a security personnel and 10 injured in an attack by suspected herdsmen on natives in Wukari and Ibi LGAs of Taraba State. Also, attack in Ibi town left 5 persons death while in Zando, Wusen, Gburmela villages left 5 killed (Vanguard news, 27 ${ }^{\text {th }}$ February 2016). Chairman Youth Vision Taraba State Mr. Audu kefas told Vanguard on Saturday that farmers within these affected areas have deserted their villages for fear of further attacks (Vanguard News, 27 $7^{\text {th }}$ February, 2016). 40 people killed in Enugu and 11 houses burnt. A victim confessed thus, "they pursued and killed my friend and shot at me several times but missed, they caught up with me and used machetes on me until I lost consciousness (Vanguard News, $26^{\text {th }}$ April, 2016). Gov. Rochas Okorocha "it is a national issue, not ethnic". The Ohanaeze spoke by saying that "cattle owners not herdsmen should be questioned". Furthermore, the Ohanaeze stated " it's a failure of government" (Vanguard News, 26 ${ }^{\text {th }}$ April, 2016). Remembering the Agatu Massacre; more than 5500 persons lost in clashes between farmers and herdsmen from 2013 to 2017 in Agatu community (Vanguard news, 21 $1^{\text {st }}$ January, 2017). Fresh attacks in Kaduna state (Birnin Gwari) by alleged herdsmen leaving 10 killed 
(Premium Times News, 14 $4^{\text {th }}$ January, 2018)... this brought reactions even by Senator representing Kaduna Central Sen. Shehu Sani. At least 70 persons including three policemen were killed in suspected herdsmen attacks on villages in Benue between December $31^{\text {st }} 2017$ and January 8 - mass burial for victims took place on the $12^{\text {th }}$ January (Premium times, $14^{\text {th }}$ January, 2018). The president ordered that the Inspector General of Police moves down to Benue to beef of security.

\section{Events before, during and after the blood bath}

1. The enactment of anti-open grazing bill in Ekiti state $\left(31^{\mathrm{si}}\right.$ August, 2016), then Benue ( $1^{\text {st }}$ November, 2017) and then Taraba (enacted June $24^{\text {th }}, 2017$ to take full implementation 6 months after - January, 2018)

2. More support for anti-open grazing bill across states such as Enugu, Abia, Delta, and other South Western states, and the enactment of this law is to be witnessed soon across more states.

3. Government deployment of securities to the affected regions after the dusk.

\section{Perspectives, opinions, statements, about these events}

1. Arewa Consultative Forum set up committee in respond to the Benue killings, and also to advise appropriately (Punch News, $13^{\text {th }}$ January, 2018)

2. Ijaw Youth Congress support the anti-open grazing stance across some states and frown at the carnages across the county (Punch News, $13^{\text {th }}$ January, 2018)

3. MASSOB condemns the carnage by alleged herdsmen and proclaimed more support for the anti-open grazing bill (Punch News, $13^{\text {th }}$ January, 2018)

4. Miyetti Allah condemns the anti-open grazing law enacted in Benue saying it is a time bomb

5. Gani Adams (Coordinator Oodua Peoples' Congress - a Yoruba umbrella group) applauded Gov. Ayo Fayose for passing the antiopen grazing bill (Naijanews.com. 29 $9^{\text {th }}$ August, 2016).

6. Condemnation of the anti-open grazing bill by Fulani youths in Benue state.

7. Ondo farmers beg FG for protection against herdsmen (Channels, $13^{\text {th }}$ January, 2018)

8. Nigerias union must be renegotiated said Pastor Tunde Bakare (Channels, 14 ${ }^{\text {th }}$ January, 2018).

9. Former head of state Gen. Babangida calls for urgent solution to killings in Nigeria (Channels, 14 ${ }^{\text {th }}$, January, 2018)

10. Paul Unongo to President Buhari "'End carnage in Benue state" (New Telegaph, 12 ${ }^{\text {th }}$ January, 2018)

11. " if federal government can't protect us, we will raise arms"Paul Unongo (Sahara reporters, $12^{\text {th }}$ January, 2018)

12. "Stop weeping, arm Benue people to defend themselves" ( Itse Sagay - National Accord, $12^{\text {th }}$ January, 2018)

13. "I blame attacks on Federal Government's inability to respond as expected and also the security" (Gov. Samuel Ortom - Punch News, 14 ${ }^{\text {th }}$ January, 2018).
14. "Our society unfortunately operates a reward and complicit system for violence. The villains are cuddled and remunerated and the victims are blamed" Sen. Shehu Sani

\section{Current perspectives}

Retrospectively, a lot has happened over the couple of years and heightened cases of insecurity are still witnessed across the country. In a more realistic sense, it will be good for us to look through certain factors that might have led to this. Firstly, as Kazah-Toure ${ }^{1,2}$ posits: Citizenship in the operational 1999 Constitution of the Federal Republic of Nigeria is fundamentally defined in the most primordial terms of consanguinity, of tracing ancestral origin to a particular community considered as indigenous in the country. Constitutional provisions and the concrete practices, at the levels of both the state and partly society, do not help the future of the country in relation to its tackling the citizenship problematic. Millions of citizens are denied some rights where they reside on the basis of their being classified as non-indigenes, that are they are treated as settlers within their immediate local communities - even if they were born, bred, continuously work and pay taxes there. Important also is the syndrome or parlance such as the 'son of the soil' - hardly daughter. Meaning inclusion, within geography and location, this contrasts with other citizens that are not perceived as such, meaning exclusion. Citizens fitting into the classification as the native, indigene or 'son of the soil', in a given community, may not be residing in the area - but can benefit from citizenship rights no matter the years of having been absent from the location, but those categorized as 'settlers' have all sorts of obstacles concerning citizenship rights. Thus, a core political and social problematic Nigeria faces increasingly, on citizenship, is the indigene (native or son of the soil issue) and non-indigene or settler perceptions and practices, despite the reality that both the included and excluded are citizens of Nigeria. ${ }^{2}$ Additionally, the population increase, the migration, the climate change effect, desertification, the conflict in the North East and a host of other factors are likely to account for this. Furthermore, due to climate change effect on the Lake Chad Basin around the North Eastern part of Nigeria, and some other factors, the middle belt is gradually getting densely populated as it is currently witnessing the influx of men, women, and animals, basically for food, succor, shelter, etc. To complicate the situation further is the insurgency in the North Eastern part of Nigeria and other forms of instability across others parts of the country creating a need for people and cattle to move to a land that can cater for humans and animals. The Sahel and Sudan savanna(s) which contains the major part of the North is faced with the adverse condition of climate change and desertification. The pastoralist will have to seek for a new vegetative land to be able to meet up with the condition of the times.

\section{Population competing on resources}

The population here out weights the available resources. In a way, because of pre-existing fear of settler /indigene conflict, a new tension is sent across about personal space. The natives of these states are at high alert to watch out for new influx, while the new settlers are trying to find a place to settle; this scenario alone comes with its own kind of tension. Looking at the resources in Benue State (food basket of the nation), the fertile land in Plateau and the food crops, the good soil in Nassarawa state, Kaduna, Adamawa and Taraba, this influx of persons will have to depend on what is available. Economically, it expands on the economic power of the state as these new faces will come even 
with their economic resources to the benefit of the state but then the tension it creates makes the whole communities volatile.

\section{Changing the narratives}

A friend asked me this on the $12^{\text {th }}$ of January at exactly 8:15 PM; "can you proffer a solution to the incessant attacks on farmers by herdsmen?. I was shocked but my reply was that "I am not sure, but I have written an article on this". He went further to say that "we cannot keep criticizing without proffering solutions. It means we're not any better" and I now replied, "the issue is at the fore burner and the heat is on our leaders because they have the resources, the will power and what is happening now is sure to happen; with displacement in the North East, the climate change, etc. The issue is now recurrent, and should be mediating not catalyzing." The wave of this insecurity may likely prompt further anarchy if not addressed as people may seek alternative violent measures in the name of self defense. In dealing with this, most of the actions taken by government have always being to condemn and mostly stops at that. Realizing that the solution to this situation may not be so easy to single out, perhaps part of the reasons why our leaders have not been able to draw out solutions to this. Looking at the Fayose's template, it has worked for Ekiti. Fayose had to set up an Ekiti Anti grazing Enforcement Marshal to collaborate with Local Governments and the herdsmen association in Ekiti and evidently it has yielded a lot of progress. This is one approach that worked! I strongly belief that the beginning of our problem in this country is the reward system. Once you fail to punish an unwanted behavior, there is every tendency that it turns into an unwanted habit (from opinion pools - This advocates for consistent punishment of offenders). This approach may yield good result when used appropriately. There are five "P" that must be stopped to end the murderous activities of herdsmen; stop protecting them, stop politicizing them, stop paying them, stop prevaricating on them, stop pampering them. (Sen. Shehu Sani, $7^{\text {th }}$ January, 2017 twitter handle). This is also a good point from the point of action and not just rhetorics. Looking at the trend of happenings, we will need to restructure our security fabrics and ensure it delivers on its core mandate (Opinion pools - I couldn't agree less) Every Nigerian will have to sow the seed of national consciousness and patriotism to be able to mitigate the current challenges we are faced with (Opinion pools - I agree with this).

Looking at how dicey the situation has been, government is faced with intervention at four or more levels

1. Government will have to provide security to protect the remaining survivors

2. Arrest the perpetrators

3. Provide medical care and even mental health care to survivors

4. Mediate existing conflicts. Government may also act in other ways not suggested here.
Government will have to employ high level of consultation to deal with these challenges that the different levels. Also, the survivors would be seen to operate at different level of distress. Some to show mild symptoms of distress, others to show moderate, others to show severe, and other to show profound level of psychological distress; and government will also be responsible in ensuring that these individuals identified as people in need are helped to restore full or relative functioning. Most importantly is the number of human groups that are displaced that will need help from different levels of intervention from the Mental Health and Psychosocial Support Services Pyramid

Level 1: Basic services (food, security, medical care, shelter, clothing, etc)

Level 2: Strengthening their family linkages, the community ties, restoring family links, etc.

Level 3: providing focused on specialized services to survivors of gender based violence, counseling services, etc

Level 4: provision of specialized mental health services (Psychotherapy, medications, etc)

Just to put this as a caveat, that the survivors of this dreaded attacks will have to be subjected to good and quality mental health assessment because these traumatic events may just remain in the unconscious minds to come up in the nearest future with a slight trigger.

\section{Conclusion}

In conclusion, government action towards mitigating this carnage should be mediating rather than catalyzing; and government should also communicate clearly its intensions while it demands for strict adherence. Furthermore, the people will have to seek redress in ways needed by ensuring that arrest and punishment of perpetrators of any sort of crime is being implemented to a more functional state. This paper further suggests that more qualitative studies should be carried out, engaging more Focused Group Discussions, centered on the problem and the solution by the participants; this will help to bring in both aggrieved persons to a front, hence suggestions to improve the state of being across these vulnerable areas.

\section{Acknowledgment}

None.

\section{Conflict of interest}

Authors have declared no conflict of interest.

\section{References}

1. Kazah-Toure T. Kaduna: Human Rights Monitor. Ethno-Religious Conflict in Kaduna State. 2003.

2. Kazah-Toure T. A Discourse on the Citizenship Question in Nigeria. Democracy \& Development. Journal of West African Affairs. 2004;4(1):41-63. 